Zbornik Instituta za kriminološka

i sociološka istraživanja

2021 / Vol. XL / 1 / 25-49

Originalni naučni rad

Primljeno: 11. marta 2021. godine

Prihvaćeno: 1. aprila 2021. godine

DOI: $10.47152 /$ ziksi2021012

UDK: 364-786:343.261-052

\title{
RESTORATIVNI PERFORMANS I RESOCIJALIZACIJA OSUĐENIH LICA*
}

\author{
Ana Batrićević* \\ Marina Kovačević
}

„Dođi, dođi, ko god da jesi, bilo da bježišs, tražiš ili lutaš, to više važno nije.

Dođi, ovdje ne broje se grijesi, čak i ako si posrnuo hiljadu puta, dođi, dođi, dođi što prije.“

Mevlana Dželaludin Rumi ${ }^{1}$

Polazeći od dosadašnje uspešne primene umetnosti (pozorišta, književnosti, slikarstva) u cilju resocijalizacije $i$ socijalne reintegracije osuđenih lica, autorke kao predmet rada razmatraju uvođenje, kako u teoriju tako $i$ u praksu, pojma restorativnog performansa kao inovativnog pristupa u radu sa prestupnicima. Nakon analiziranja pojma i karakteristika restorativnog procesa sa jedne i performansa (sa fokusom na pozorišni performans) sa druge strane, autorke

\footnotetext{
* Ovaj rad nastao je kao rezultat istraživačkog angažovanja prema Planu i programu rada Instituta za kriminološka i sociološka istraživanja za 2021. godinu.

* Viši naučni saradnik na Institutu za kriminološka i sociološka istraživanja u Beogradu. Email: a.batricevic@yahoo.com

* Direktor Instituta za performativne umetnosti i socijalni rad - Centar za rehabilitaciju imaginacijom i doktorand na Fakultetu dramskih umetnosti Univerziteta u Beogradu. Email: marina_the_first@hotmail.com

${ }^{1}$ Mevlana Dželaludin Rumi (1207-1273), persijski islamski filozof, teolog, pravnik, pesnik i sufijski mistik. Citirano prema:Safransky, S. (ed.) (1990). Sunbeams:A Book of Quotations. Berkeley, CA: North Atlantic Books, 67.
} 


\title{
Zbormik IKSI, 1/2021 - A. Batrićević, M. Kovačević \\ „Restoratiuni performans i resocijalizacija osuđenih lica”, (str. 25-49)
}

\begin{abstract}
izdvajaju ključne dodirne tačke ova dva procesa i izvode definiciju restorativnog performansa. Potom, autorke predstavljaju primere uspešne primene ovog metoda rada sa osuđenim licima u Srbiji, analizirajući na osnovu prethodno sprovedenog kvalitativnog istraživanja, ključne restorativne elemente koji u njima dolaze do izražaja, kao bitne faktore suzbijanja recidiva. Kao osnovni cilj ovog rada, autorke se zalažu za širu primenu restorativnog performansa $i$ njegovo uvođenje u redovne programe tretmana u ustanovama za izvršenje krivičnih sankcija, uz angažovanje svih zainteresovanih strana i podršku zajednice.
\end{abstract}

KLJUČNE REČI: restorativni proces / performans / pozorište / resocijalizacija / zatvor

\section{UVOD}

Među brojnim oblicima rada sa licima lišenim slobode, umetnost se sve više koristi kao medij za njihovo osnaživanje, čime se postiže autonomija, emancipacija, razvoj kritičkog mišljenja i pospešuje njihova socijalna reintegracija. Naučne studije u Sjedinjenim Američkim Državama (McArthur, Law, 1996; Fiske, 1999) i Velikoj Britaniji (McLewin, Gladstone, 2002; Wrench, Clarke, 2004) potvrdile su da umetnost može imati uspešnu primenu u tretmanu i rehabilitaciji prestupnika i time doprineti prevenciji kriminaliteta (Farrier, Froggett, Poursanidou, 2009: 61). Primer umetničke, ali i obrazovne metodologije koja se koristi za suzbijanje opresije i borbu protiv različitih vrsta socijalnih nejednakosti predstavlja i proces primenjenog pozorišta, koje je zahvaljujući svojoj dinamičnoj prirodi i transformativnoj snazi prepoznato kao delotvoran metod osnaživanja osuđenih lica.

Polazeći od dosadašnje uspešne primene umetnosti, a posebno pozorišne, u resocijalizaciji osuđenih lica, predmet ovog rada obuhvata teorijsko koncipiranje pojma restorativnog pozorišnog performansa, izvedenog iz pojma primenjenog pozorišta, a zasnovanog na osnovim principima i simbolici restorativne pravde, kao i analizu njegovih kapaciteta primarno na polju resocijalizacije i reintegracije osuđenih lica, a posredno i na polju prevencije kriminaliteta. Pored toga, u radu su predstavljena dosadašnja iskustva u Srbiji u oblasti primene restorativnog performansa osuđenih lica, a na osnovu prethodno sprovedenog kvalitativnog istraživanja autorki, ukazano je na ključne restorativne elemente koje ovu vrstu performansa prožimaju. Takođe, istaknute su moguće implikacije ovakvog inovativnog pristupa na uspešnost rehabilitacije i socijalne reintegracije osuđenih lica. Predmetom rada obuhvaćena je i kritička analiza aktuelnih i potencijalnih ograničenja prilikom realizacije programa resocijalizacije kroz restorativni pozorišni performans, posebno u našoj zemlji, kao i formulisanje preporuka i smernica za širu primenu takvih programa $\mathrm{i}$ njihovo uključivanje $\mathrm{u}$ redovne programe tretmana prestupnika u budućnosti. 


\section{Zbormik IKSI, 1/2021 - A. Batrićević, M. Kovačević \\ „Restorativni performans i resocijalizacija osuđenih lica”, (str. 25-49)}

Ciljevi rada obuhvataju: definisanje pojma restorativnog performansa čiji je smisao da kroz specifičan performativni proces, koji sadrži restorativne elemente, doprinese resocijalizaciji prestupnika, kao i njegovo uvođenje u kako u pozorišnu umetnost tako i u naučne discipline koje se bave proučavanjem resocijalizacije prestupnika, poput penologije, kriminologije, penološke andragogije i drugih povezanih oblasti. Svrha ovoga rada jeste i podizanje svesti stručne i šire javnosti (zajednice) o domašajima i kapacitetima restorativnog performansa kao važnom i značajnom pedagoškom i andragoškom instrumentu koji može da posluži kao sredstvo postizanja društvenih promena. Takođe, nastoji se i podići svest zajednice o restorativnom performansu kao mediju koji doprinosi osnaživanju pojedinca i pruža mogućnost socijalne rehabilitacije, refleksije, osvešćivanja i dijaloga, a za krajnji cilj ima resocijalizaciju, emancipaciju i socijalnu reintegraciju svih svojih učesnika. Radom se nastoji uticati na promovisanje šire primene restorativnog performansa $u$ redovnim programima tretmana i resocijalizacije osuđenih lica u ustanovama za izvršenje krivičnih sankcija u Srbiji.

\section{RESTORATIVNI PROCESI I RESOCIJALIZACIJA OSUĐENIH LICA}

Tradicionalna krivičnopravna reakcija na kriminalitet, svojstvena socijalnom kontekstu državne moći, koja u prvi plan postavlja krivično delo i učinioca, a zanemaruje potrebe žrtve, našla se na meti opravdanih kritika sedamdesetih i osamdesetih godina dvadesetog veka (Ćopić, 2015: 14-15). Pokazalo se da krivičnopravna represija nije dala očekivane rezultate (Dimovski, 2012: 363). Retributivni pristup kazni каo odmazdi za učinjeno krivično delo (Stojanović, 2018: 225), zasnovan na ideji da učiniocu treba naneti zlo "prema zasluzi“, proporcionalno težini učinjenog krivičnog dela (Vasiljević-Prodanović, 2011: 519), kako bi on "svojom patnjom platio za prestup" (Milevski, 2013: 40) nije u skladu sa savremenim trendovima kriminaliteta (Soković, 2012) i relevantnim međunarodnim dokumentima (Ćopić, 2015: 15). Osim toga, smatra se da je retributivni pristup izneverio očekivanja i zbog toga što je mahom obuhvatao marginalizovane društvene grupe poput beskućnika, osoba sa mentalnim smetnjama, socijalno ugroženih i pripadnika manjina (Kostić, 2007: 9)

Podstaknuta idejama savremenog penalnog/kaznenog populizma (Soković, 2012: 95; Ignjatović, 2017: 12) prekomerna primena krivičnopravne represije, a posebno kazne zatvora je, umesto da doprinese suzbijanju kriminaliteta, proizvela niz negativnih posledica, uključujući: prenaseljenost zatvora i nehumane uslove života osuđenih (Ilić, 2011: 245; Radojković, 2014: 7; Spasojević, Janković, Kovačević, 2018: 7; Tanjević, 2019: 156), zatvorske deprivacije (Ilijić, 2014: 78; Petrović, Jovanić, 2018:479; Špadijer-Džinić, Pavićević, Simeunović-Patić, 2009: 226), razvoj neformalnog zatvoreničkog sistema (Ilijić, 2012: 233; Mirić, 2012: 66), stigmatizaciju (Macanović, Nadarević, 2014: 100), auto-stigmatizaciju (Đorović et al., 2020: 12) i neuspešnu socijalnu reintegraciju bivših osuđenika (Jovanić, Nestorović, Petrović, 2019: 274). Kao krajnji ishod takvog pristupa javlja se "kriminalna infekcija" (Jovanić, Petrović, 2017: 100) koja rezultuje porastom stope 


\section{Zbormik IKSI, 1/2021 - A. Batrićević, M. Kovačević \\ „Restorativni performans i resocijalizacija osuđenih lica”, (str. 25-49)}

recidivizma (Knežić, 2017: 203). Zbog toga sve više krivičnopravnih sistema pribegava uvođenju različitih alternativnih sankcija, mera i vidova postupanja, uključujući i rešenja sa elementima restorativne pravde i prema maloletnim i prema punoletnim prestupnicima (Nikolić-Ristanović, Konstantinović-Vilić, 2018: 319). Restorativni princip nije u potpunosti eliminisao princip retribucije ali ga podređuje nastojanju da se namesto kažnjavanja ponovo uspostave veze između prestupnika, žrtve i zajednice (Farrier, Froggett, Poursanidou, 2009: 62).

Restorativna pravda podrazumeva specifičan pristup rešavanju sukoba, koji polazi od potreba žrtve, učinioca i zajednice, okupljajući sve zainteresovane strane da bi im se pomoglo da zajedno, mirnim putem i dijalogom razreše svoje sukobe i sporazumeju se o popravljanju štete, odnosno otklanjanju posledica kažnjivog dela (Kostić, 2007: 6, Copić, Nikolić-Ristanović, 2018: 386). Restorativna pravda uključuje proces u kojem sve strane uključene u konkretan slučaj zajedno rešavaju kako će izaći na kraj sa posledicama krivičnog dela i njegovim odražavanjem na budućnost (Marshall, 1998: 8, prema Ćopić, 2007: 28), a njenu suštinu sačinjavaju: komunikacija, dijalog, odnosno proces, i to mnogo više nego ishod (Ćopić, 2007: 29).

Ideja restorativne pravde afirmisana je i u međunarodnim dokumentima. Deklaracija UN o osnovnim principima pravde za žrtve kriminaliteta i zloupotrebe moći iz 1985. godine, predviđa da se, kada god je moguće, primene neformalni mehanizmi za rešavanje konflikata, uključujući posredovanje, arbitražu i običajno pravo i praksu, da bi se obezbedilo pomirenje strana u sukobu i obeštećenje žrtve. ${ }^{2}$ Restorativni pristup dobija sve širu primenu u vidu: posredovanja između žrtve i učinioca, porodične i društvene rasprave, programa intervencije od strane žrtve, krugova kažnjavanja, krugova mirotvorstva, panela na kojima se žrtva obraća učiniocima, rada u korist žrtve ili lokalne zajednice, grupa u okviru društvene za podršku žrtvama ili učiniocima krivičnih dela (Ćopić, 2007: 27), mirenja i naknade štete (Kostić, 2007: 12). Programima restorativne pravde smatraju se svi programi koji se zasnivaju na restorativnom procesu i/ili teže ostvarivanju restorativnih ciljeva, kako je i istaknuto u Deklaraciji UN o osnovnim principima primene programa restorativne pravde u krivičnim slučajevima iz 2000. godine3 (Ćopić, 2007: 30).

Među restorativnim ciljevima izdvaja se postizanje sporazuma koji omogućava reparaciju za žrtve i zajednicu, ali i reintegraciju žrtve i učinioca krivičnog dela kroz restorativni proces, koji uključuje sve zaiteresovane strane (Ćopić, 2007: 30) i istovremeno promoviše reintegraciju učinioca krivičnog dela i popravljanje odnosa između žrtve, učinioca i zajednice (Kostić, 2007: 6). Pri tome se reintegracijom učinioca krivičnog dela smatra učenje kako da se vrati u društvenu zajednicu, sa

\footnotetext{
${ }^{2}$ UN General Assembly, Declaration of Basic Principles of Justice for Victims of Crime and Abuse of Power, adopted by the General Assembly, 29 November 1985, A/RES/40/34, dostupno na: https://www.refworld.org/docid/3boof2275b.html, stranici pristupljeno 16.02.2021.

3 UN Economic and Social Council (ECOSOC), UN Economic and Social Council Resolution 2002/12: Basic Principles on the Use of Restorative Justice Programmes in Criminal Matters, 24 July 2002, E/RES/2002/12, dostupno na: https://www.refworld.org/docid/46c455820.html, stranici pristupljeno 16.02.2021.
} 


\section{Zbormik IKSI, 1/2021 - A. Batrićević, M. Kovačević \\ „Restorativni performans i resocijalizacija osuđenih lica”, (str. 25-49)}

fokusom na plan postupanja, a u cilju „lečenja“ nastalog štetnog postupka (Kostić, 2007: 8) na bazi izvinjenja, oproštaja, povezivanja članova zajednice (Kostić, 2007: 13) i njenog jačanja kroz jedan smislen, simboličan ritual (Rossner, Bruce, 2016: 107-125).

Iako se često sagledava samo u kontekstu ličnih osećanja, oproštaj ima i svoje komunikativne i socijalne dimenzije, koje upravo predstavljaju okosnicu teorije i prakse restorativne pravde (Dzur, Wertheimer, 2002: 3). Naime, cilj restorativne pravde ne iscrpljuje se samo u pomirenju na interpersonalnom nivou - između žrtve i prestupnika, već on podrazumeva i pomirenje na širem, društvenom nivou između prestupnika i zajednice (Dzur, Wertheimer, 2002: 3). Ova, socijalna dimenzija restorativne pravde se produbljuje kroz različite oblike uključivanja zajednice u restorativne procese (Rossner, Bruce, 2016: 107-125), uključujući i dobrovoljno uključivanje njenih predstavnika u pojedine restorativne programe, čime se na simboličan način pokazuje njena zainteresovanost za pomirenje žrtve i prestupnika, ali i za reintegraciju prestupnika (Dzur, Wertheimer, 2002: 3). Zajednica igra ključnu ulogu kao neutralna, treća strana u restorativnom procesu (Rossner, Bruce, 2016: 107-25), tako što prepoznaje i uvažava štetu pričinjenu žrtvi i opravdanost njenog nezadovoljstva, dok istovremeno prihvata prestupnike kao ljudska bića kojima treba omogućiti da se ponovo vrate u zajednicu (Dzur, Wertheimer, 2002: 7). Štaviše, zajednica je dužna da učestvuje u komunikaciji između žrtve i prestupnika, a, u odnosu na žrtvu, ta dužnost proizlazi iz okolnosti da zajednica nije uspela da joj pruži adekvatnu zaštitu (usled čega je došlo do viktimizacije), dok u odnosu na prestupnika dužnost zajednice proističe iz njenog propusta da mu omogući adekvatnu socijalizaciju, obrazovanje i integraciju (Dzur, Wertheimer, 2002: 7).

Primena savremenih teorija u mikro sociologiji (Mimica, Bogdanović, 2007: 327) i sociologiji emocija (Mimica, Bogdanović, 2007: 540-541; Simonović, 2008: 150-152; Kišjuhas, 2017: 385-386) može doprineti sagledavanju mehanizma funkcionisanja restorativne pravde kroz interakciju, ritual i solidarnost (Rossner, 2011: 96). Teorija rituala interakcije (Simonović, 2008: 152; Hausmann, Jonason, Summers-Effler, 2011: 319-329) potiče od Dirkema, koji teoriju rituala zasniva na ličnim emocijama i kao ključne ističe sledeće funkcije rituala:pružanje radosti, unutrašnjeg mira i moralne utehe (Scheff, 1983, prema Kišjuhas, 2015: 240). Ovu teoriju preuzima i dalje razvija Gofman, koji je isticao da rituali imaju funkciju otvaranja i zatvaranja susreta, održavanja društvene interakcije i da izazivaju emocije kada su usmereni ka individualnom sopstvu, kao zajedničkom „totemu“ (Goffman, 1967, prema Kišjuhas, 2015: 241).

Prema Collins-u (Collins, 2004 prema Rossner, 2011: 96), tokom uspešnih rituala se vremenom razvija određeni konverzacijski i telesni ritam, što se pokazuje kroz zajedničko usmeravanje pažnje i međusobno razumevanje koje kulminira u vidu osećanja solidarnosti i pripadanja grupi, a prožeto je snažinim pozitivnim emocijama (Kišjuhas, 2017: 385-386). Polazeći od širokog spektra susreta i situacija, Collins pokazuje da se ove ritualne komponente proistekle iz interakcije izgrađuju, raspoređuju, i, što je najvažnije, da se mogu empirijski uočiti (Collins, 2004 prema Rossner, 2011: 96). Navedene ritualne komponente prisutne su u restorativnim 


\author{
Zbormik IKSI, 1/2021 - A. Batrićević, M. Kovačević \\ „Restorativni performans i resocijalizacija osuđenih lica”, (str. 25-49)
}

procesima, a posebno dolaze do izražaja u kontekstu pozorišnog performansa kao jednog od njihovih metoda.

\title{
2. POZORIŠNI PERFORMANS KAO JEDAN OD METODA RESTORATIVNIH PROCESA
}

Izraz performans (engl. performance) doslovno se prevodi kao "izuršenje“ ili "predstava", "postizanje", "predstavljanje", "delo" ili "sastav" i u najširem smislu označava svako događanje/izvođenje na sceni ili nekom drugom prostoru (Zdravković, 2013: 152). Performans se opisuje kao "improvizvani ili režirani kulturni događaj sa multimedijalnim obeležjima u kojem učestuuju umetnici različitih profila - muzičari, glumci, pesnici, slikari, vajari i drugi“, odnosno kao "scenski igrokaz u okviru kojeg je moguće i uključivanje publike" (Klajn, Šipka, 2006: 927). Da performans treba sagledavati kao proces, čija je suština sam čin izvođenja a ne cilj koji se tim izvođenjem želi postići, potvrđuje i tumačenje izraza „performativan“ (engl. performative) kao „onaj koji samim svojim izricanjem ostvaruje radnju koju opisuje,, (Klajn, Šipka, 2006: 927). U svojoj biti performans predstavlja "ponašanje u kome se analizira društvena artificijelnost skrivena iza prirodne doslovnosi" (Jovićević, Vujanović, 2007: 13). Tako koncipiran, pojam performansa obuhvata i pozorišne predstave u najširem smislu, ali nije nužno ograničen na njih. Međutim, kako su u fokusu ovog rada upravo pozorišni performans i njegova uloga u resocijalizaciji osuđenih lica kroz restorativne procese, potrebno je najpre ukazati na određene karakteristike performansa, koje su relevantne sa tog aspekta i koje zapravo predstavljaju dodirne tačke pozorišnog performansa i restorativnog procesa.

Performativni iskaz (poput pozorišne predstave) uvek je usmeren na neku zajednicu, koju u određeno vreme predstavlja upravo publika koja mu prisustruje, te u tom smislu označava izvođenje jednog socijalnog akta (Fischer-Lichte, 2009: 18). Pozorište predstavlja mesto susreta publike sa jedne i aktera predstave sa druge strane, pri čemu svaka ove dve suočene grupe ljudi fizički zauzima svoj prostor, ali su ljudi iz svake grupe zapravo celim bićem, čulima, emocijama i maštom okrenuti ka "suprotnoj” grupi (Turčilo, Kolčaković, 2009: 105). Iako učesnici u pozorišnoj predstavi ne gledaju sve vreme u publiku, kao što publika gleda u njih, oni svoje delovanje projektuju ka gledaocima, čineći kroz reči i pokrete razumljivim ono što se dešava na sceni (Turčilo, Kolčaković, 2009: 105). Čin izvođenja i čin njegove recepcije odvijaju se kao realna aktivnost ovde i sada, što mu daje jedinstven kvalitet (Jovićević, Vujanović, 2007: 8). U tom smislu, izvođenje predstavlja deo života koji izvođači i publika provode zajedno, u istom prostoru gde se odvija izvođenje i gledanje (Jovićević, Vujanović, 2007: 8). Akcija dolazi sa scene, a reakcija iz sale (Jevtović, 2001), pri čemu se uspostavlja kontakt, "kolo pažnje" koje učesnici u predstavi doživljavaju kao odobravanje i podršku (Turčilo, Kolčaković, 2009: 105). Na taj način, kreira se osobena zajednica aktera i gledalaca, čime im se omogućava da dožive iskustva koja su im do tada bila uskraćena i iniciraju odgovarajuće procese promene (Fischer-Lichte, 2009: 57). 


\section{Zbormik IKSI, 1/2021 - A. Batrićević, M. Kovačević \\ „Restorativni performans i resocijalizacija osuđenih lica”, (str. 25-49)}

Iniciranje takvih promena, kako na individualnom, tako i na širem, društvenom nivou najviše dolazi do izražaja kada je u pitanju takozvano primenjeno pozorište, koje se u najširem smislu određuje kao "ono što se događa kada grupa ljudi koja radi sa zajednicom koristi pozorišne tehnike za rešavanje problema od društvenog značaja" (Theatre Development Fund, 2014).

Primenjeno pozorište počiva na Freireovoj metodologiji osvešćivanja dijalogom $u$ interdisciplinarnom istraživanju zajedničkih tema, a sa ciljem otkrivanja uzroka koji su doveli do stvarnosti u kojoj vlada obespravljenost (Freire, 2005: 87-125). Polazeći od Freirovih ideja, Augusto Boal je razvio svoj koncept pozorišta potlačenih međunarodni pokret koji vidi teatar kao sredstvo za postizanje participativne društvene promene. Zahvaljujući svojoj fleksibilnosti, Boalov model pozorišta potlačenih je veoma moćan i primenljiv u različitim zajednicama i situacijama, što potvrđuje i njegova sve šira upotreba u Evropi, Americi, delovima Afrike i Azije (Thompson, 2003: 16).

Tokom osamdesetih i devedesetih godina 20. veka, edukatori, pozorišni praktičari i kreatori politika počinju sve šire koristiti termine "primenjena drama" (applied drama), "primenjeno pozorište" (applied theatre) i "primenjeni performans" (applied performance) kako bi opisali formu dramske aktivnosti koja je postavljena izvan okvira konvencionalnih, uobičajenih pozorišnih institucija i usmerena ka dobrobiti pojedinca, zajednice i društva (Nicholson, 2005: 2-3). Kao opšti termin, primenjeno pozorište obuhvata niz raznovrsnih praksi i metoda, čiji je cilj vraćanje pozorišta tamo gde ono zapravo i pripada - među „obične“ ljude. „Primenjeno“ podrazumeva da se pozorišna praksa iznosi iz opskurnih "crnih kutija”, i vraća nazad na otvoreno (Thompson, 2003: 19). Praksa primenjenog pozorišta podrazumeva intervenciju, komunikaciju, razvoj i osnaživanje u radu s pojedincima ili specifičnim zajednicama (Nicholson, 2005: 3). Projekti primenjenog pozorišta često se realizuju na različitim i sasvim neočekivanim mestima, kao što su:izbeglički kampovi, bolnice, ustanove za osobe sa mentalnim smetnjama, domovi za stara lica, ulice, škole, bolnice, muzeje i zatvori (Nicholson, 2005: 28, Hartley, 2012).

Kao veoma širok pojam, primenjeno pozorište se pre svega odlikuje inkluzivnošću, što potvrđuje i raznolikost praksi koje se podvode pod ovaj pojam: pozorište za razvoj (Theatre for Development), pozorište u obrazovanju (Theatre in Education), pozorište u zatvoru (Prison Theatre), pozorište za zajednicu (Communty Theatre), socijalno pozorište (Social Theatre), participativno pozorište (Participatory Theatre), dramaterapija (Dramatherapy), psihodrama (Psychodrama), popularno pozorište (Popular Theatre), muzejsko pozorište (Museum Theatre), pozorište potlačenih (Theatre of the Opressed) (Thompson, 2003: 14-16; Nicholson, 2005: 3), legislativno pozorište (Legislative Theatre) (Ilić, 2017: 39). Primenjeno pozorište prilagođava se socijalnom i kulturnom kontekstu i potrebama korisnika, a njegovi praktičari se danas najviše bave potrebama društveno osetljivih grupa koje su pogođene negativnim promenama u određenom razdoblju, kao i osnaživanjem različitih isključenih, marginalizovanih (Thompson, 2003: 15) i represiranih grupa osuđenih lica, migranata, izbeglica i beskućnika (Thompson, 2003: 201). Zahvaljujući metodama utemeljenim na igrama i simulacijama uz pomoć kojih se stvara ambijent oslobođen tradicionalnih konvencija (Hartley, 2012: 82) koji 


\section{Zbornik IKSI, 1/2021 - A. Batrićević, M. Kovačević \\ „Restorativni performans i resocijalizacija osuđenih lica”, (str. 25-49)}

pomaže učesnicima da se lakše suoče i izbore sa problemima, događajima ili pitanjima, analizirajući svoje i tuđe postupke, primenjeno pozorište predstavlja put za transformaciju u izazovnim okruženjima (Thompson, 2003: 16; Taylor, 2003 prema Gjaerum, 2014: 351).

Polazeći od opisanog odnosa između izvođača u pozorišnoj predstavi i publike, može se uočiti niz dodirnih tačaka između pozorišnog izvođenja i restorativnih procesa, što ima svoje korene još u antičkom pozorištu a naročito dolazi do izražaja kod primenjenog pozorišta. Antičko pozorište imalo je religiozno poreklo i suštinsko laički karakter, obeležen ritualnim elementima (Paduano, 2011: 11). Ovi ritualni elementi, kao i laički karakter, upravo odlikuju i restorativne procese, kao što je prethodno objašnjeno.

Osnaživanje svih učesnika predstavlja jedan od ključnih elemenata restorativnog procesa. Ono se određuje kao multidimenzionalni socijalni proces koji pomaže pojedincima da steknu kontrolu nad svojim životima i koja pruža snagu za rešavanje pitanja koja oni prepoznaju kao važna u vlastitim životima, zajednicama i društvu (Czuba, 1999: 1-5) i u velikoj meri zavisi od obrazovanja (Perkins, Zimmerman, 1995: 569-579). Od antičkih vremena, obrazovanje se realizovalo ne samo kroz nauku, već i kroz umetnost (posebno književnost i dramu), koja je služila kao način za ospokojenje i umirenje duše i koja je imala ne samo estetsku, već i etičku i političku funkciju. U tom smislu, pozorište se može smatrati obrazovnom institucijom, s tim što se oblici njegovog obrazovnog i andragoškog dejstva razlikuju od pozorišta do pozorišta i od predstave do predstave (Turčilo, Kolčaković, 2009: 106). Tako shvaćeno, pozorište kao poseban vid obrazovanja doprinosi osnaživanju onih koji u njemu učestvuju, bilo da je reč o izvođačima, bilo o publici. Takvo osnaživanje, sprovedeno kroz obrazovni aspekt pozorišnog rada poprima restorativni karakter kada su njegovi učesnici i/ili publika učinioci i/ili žrtve krivičnih dela. O njegovom restorativnom karakteru se naročito može govoriti u situacijama kada učešće učinilaca krivičnih dela u pozorišnom radu ima za jedan od ciljeva njihovo podučavanje novim znanjima i veštinama (posebno socijalnim) kako bi im se olakšala socijalna reintegracija.

I u restorativnom procesu, i u pozorišnom performansu dolazi do okupljanja zainteresovanih strana na jednom mestu u određeno vreme, pri čemu su u slučaju restorativnog procesa to učinilac, žrtva i zajednica, dok su u pozorištu to izvođači (koji mogu biti učinioci i/ili žrtve krivičnih dela) i publika kao predstavnik zajednice. U oba slučaja, dolazi do interakcije između zainteresovanih strana, pri čemu se između njih ostvaruje intenzivna razmena emocija, krunisana zajedničkim ritualnim oslobađanjem emocija - nekom vrstom katarze. U slučaju restorativnih procesa, taj trenutak bi se mogao porediti sa oproštajem koji zajednica i žrtva daju prestupniku, odnosno obeštećenjem i zadovoljenjem koje zajednica i prestupnik pružaju žrtvi. Kod pozorišnog performansa taj trenutak obeležen je i proživljen od strane učesnika na jedan simboličan način: izvođači (prestupnici i/ili žrtve) kroz svoj umetnički čin pružaju publici (oličenju zajednice) nešto lepo, korisno i dobro, deleći sa njom kroz izvedbu predstave svoja osećanja, a publika im, zauzvrat, kroz aplauz pokazuje svoju podršku, koja zapravo simbolizuje podršku zajednice na njihovom putu ka reintegraciji. 


\section{Zbormik IKSI, 1/2O21 - A. Batrićević, M. Kovačević \\ „Restorativni performans i resocijalizacija osuđenih lica”, (str. 25-49)}

Imajući u vidu prethodna poređenja, restorativni performans bi se mogao definisati kao kao proces rada učinilaca i/ili žrtava krivičnih dela na pripremanju i izvođenju nekog dela iz domena performativne umetnosti, koji ima za cilj da kroz primenu ključnih principa restorativne pravde doprinese njihovoj socijalnoj reintegraciji. Shodno tome, restorativni pozorišni performans bi se, kao uži pojam, mogao definisati kao proces rada učinilaca $i /$ ili žrtava krivičnih dela na pripremanju $i$ izvođenju pozorišne predstave, koji ima za cilj da kroz primenu ključnih principa restorativne pravde doprinese njihovoj socijalnoj reintegraciji.

Definicija restorativnog performansa data u ovom radu koncipirana je dovoljno široko da kao moguće učesnike restorativnog performansa obuhvati i učinioce i žrtve krivičnog dela, što otvara prostor da u restorativnom performansu učestvuju: 1) samo učinioci krivičnih dela; 2) samo žrtve krivičnih dela; 3) i učinioci i žrtve krivičnih dela i 4) lica koja su istovremeno i učinioci i žrtve krivičnih dela. U tri restorativna performansa analizirana u ovom radu: „Zapisi iz ćelije broj 12“, „Pravila kluba boraca“ i „O bogovima, herojima i ostalim vitezovima“, kao i u dokumentarnom filmu „Komanda ljubav“ učesnici su bili učinioci krivičnih dela, dok su u performansu „Njena priča“ učesnice bile istovremeno i učiniteljke krivičnih dela, ali i žrtve, budući da su od njih 12, čak 10 osuđene upravo zbog ubistva svog zlostavljača, dok su i preostale dve, iako osuđene zbog drugih krivičnih dela takođe bile žrtve nasilja.

Tabela 1. Dodirne tačke restorativnog procesa i restorativnog performansa

\begin{tabular}{|c|c|}
\hline $\begin{array}{l}\text { Restorativni proces } \\
\text { opšti principi }\end{array}$ & $\begin{array}{l}\text { Restorativni performans } \\
\text { osnovne odlike }\end{array}$ \\
\hline $\begin{array}{c}\text { Okupljanje zainteresovanih strana na jednom mestu u } \\
\text { određeno vreme }\end{array}$ & $\begin{array}{c}\text { Okupljanje izvođača i publike na određeno vreme na } \\
\text { mestu gde se izvodi performans }\end{array}$ \\
\hline $\begin{array}{l}\text { Prisustvo svih zainteresovanih strana: prestupnik, žrtva, } \\
\text { zajednica }\end{array}$ & $\begin{array}{c}\text { Prisustvo svih zainteresovanih strana: prestupnik i/ili } \\
\text { žrtva su izvođači na sceni, a publika simbolizuje } \\
\text { zajednicu }\end{array}$ \\
\hline $\begin{array}{c}\text { Javnost - obezbeđena kroz prisustvo nekog od } \\
\text { predstavnika zajednice }\end{array}$ & $\begin{array}{c}\text { Javno izvođenje, pred publikom kao predstavnikom } \\
\text { zajednice }\end{array}$ \\
\hline Dijalog između zainteresovanih strana & $\begin{array}{c}\text { Komunikacija između izvođača na sceni i interakcija } \\
\text { između izvođača i publike }\end{array}$ \\
\hline $\begin{array}{c}\text { Restorativni proces ne mora uvek biti profesionalnog } \\
\text { karaktera, već u nekim situacijama može biti i laičkog. } \\
\text { Naravno, to se ne odnosi na restorativne procese u kojima } \\
\text { učestvuju i profesionalci, npr. kao posrednici ili facilitatori. } \\
\text { Laički element ipak postoji kod onih restorativnih procesa koji } \\
\text { se organizuju u zajednici, od strane udruženja građana, kao što } \\
\text { su na primer programi rada sa prestupnicima u zajednici, } \\
\text { programi osnaživanja žrtava u zajednici, programi koji se } \\
\text { sprovode paralelno sa izvršenjem krivičnih sankcija prema } \\
\text { prestupnicima kao njihova dopuna, gde se sa prestupnicima } \\
\text { dodatno radi na reintegraciji, osnaživanju, podizanju svesti o } \\
\text { pravima žrtava. }\end{array}$ & $\begin{array}{l}\text { Kod pozorišnih performansa osuđenih lica, } \\
\text { neprofesionalni karakter dolazi do izražaja u dva } \\
\text { segmenta. Učesnici u performansu nisu profesionalni } \\
\text { glumci, a publiku najčešce čine „obični građani“. U } \\
\text { tom smislu, restorativni pozorišni performansi jasno } \\
\text { se odvajaju od profesionalnih izvedbi. Osim toga, } \\
\text { upravo ovi vidovi rada sa osuđenim licima ne } \\
\text { predstavljaju deo formalnog sistema, budući da se } \\
\text { sprovode od strane udruženja građana, ali uz podršku } \\
\text { institucija. }\end{array}$ \\
\hline $\begin{array}{c}\text { Iznošenje i uvažavanje emotivnih i ostalih potreba svih } \\
\text { zainteresovanih strana }\end{array}$ & $\begin{array}{c}\text { Kroz performans, izvođači sa publikom dele svoje emocije } \\
\text { i, po pravilu nailaze na određenu povratnu reakciju }\end{array}$ \\
\hline $\begin{array}{l}\text { Ritualni elementi - potiču iz samih korena restorativnih } \\
\text { procesa koji se nalaze u drevnim kulturama poput } \\
\text { Maorske; osim toga, mehanizam restorativne pravde } \\
\text { zasniva se značajnim delom na teoriji ritualne interakcije }\end{array}$ & $\begin{array}{c}\text { Začeci pozorišta, kao jednog od oblika performativne } \\
\text { umetnosti leže upravo u religijskim ritualima, o ćemu } \\
\text { svedoče žrtvenici pronađeni na scenama najstarijih } \\
\text { pozorišta }\end{array}$ \\
\hline $\begin{array}{l}\text { Simbolika - naknada štete žrtvi ne mora nužno biti u } \\
\text { realnom iznosu štete, niti je štetu odnosno zlo naneto } \\
\text { prestupom uvek moguće na taj način meriti. Zbog toga se } \\
\text { često pribegava simboličnoj satisfakciji kroz: izvinjenje }\end{array}$ & $\begin{array}{c}\text { Ako se zajednica i sama posmatra kao posredna žrtva } \\
\text { krivičnog dela (jer su njime narušeni odnosi u njoj), } \\
\text { pričinjavanje prijatnosti publici, kao oličenju } \\
\text { zajednice. kroz performans zapravo predstavlja }\end{array}$ \\
\hline
\end{tabular}


Zbormik IKSI, 1/2O21 - A. Batrićević, M. Kovačević

„Restorativni performans i resocijalizacija osuđenih lica”, (str. 25-49)

\begin{tabular}{|c|c|}
\hline prestupnika, traženje oproštaja od žrtv & simbolično iskupljenje za prestup i štetu nanetu žrtvi \\
\hline Reintegracija i žrtve i prestupnika u zajednicu & $\begin{array}{l}\text { Reintegracija žrtve i/ili prestupnika simbolično je } \\
\text { prikazana kroz klanjanje izvođača publici i aplauz na } \\
\text { kraju izvođenja, jer publika u slučaju restorativnog } \\
\text { performansa zna da su izvođači učinioci i/ili žrtve } \\
\text { krivičnih dela tako da njihov naklon sa jedne i aplauz } \\
\text { publike sa druge strane imaju mnogo dublje značene od } \\
\text { obične pozorišne formalnosti. } \\
\end{array}$ \\
\hline $\begin{array}{l}\text { Praštanje predstavlja mogući ishod restorativnog procesa: } \\
\text { žrtva prašta prestupniku i zajednici, zajednica prašta } \\
\text { prestupniku, prestupnik prašta zajednici }\end{array}$ & \begin{tabular}{|l} 
U performansu oproštaj je simboličan - može se izraziti \\
kroz samu sadržinu performansa, ali i na njegovom kraju, \\
kada se izvođači klanjaju pred publikom koja im \\
aplaudira. Klanjanje može da bude simbol traženja \\
oproštaja, ali i izražavanje zahvalnosti za drugu šansu, \\
dok bi aplauz mogao da bude posmatran kao simboličan \\
čin praštanja na strani publike, tj zajednice.
\end{tabular} \\
\hline $\begin{array}{l}\text { Pomirenje: žrtve i prestupnika, prestupnika i zajednice, } \\
\text { žrtve i zajednice }\end{array}$ & $\begin{array}{c}\text { U performansu pomirenje je simbolično - realizuje se } \\
\text { kroz sadržinu performansa, premda je, kao i oproštaj taj } \\
\text { momenta uočljiv na kraju, kada publika aplaudira } \\
\text { izvođačima }\end{array}$ \\
\hline $\begin{array}{c}\text { Priznavanje viktimizacije od strane prestupnika i zajednice } \\
\text { i uvažavanje potreba žrtve. Dakle, omogućava se da se žrtva } \\
\text { čuje, da iznese svoje mišljenje, kako ona vidi situaciju } \\
\text { nastalu izvršenjem krivičnog dela, što je i suština } \\
\text { restorativnog procesa i što ga razlikuje od klasične sudske } \\
\text { procedure i uloge žrtve u krivičnom postupku. }\end{array}$ & $\begin{array}{c}\text { Mogućnost za žrtvu da kao učesnik u restorativnom } \\
\text { performansu izrazi svoja osećanja, da se njen glas } \\
\text { čuje. Navedeno se odnosi i na situacije kada je izvođač } \\
\text { istovremeno i učinilac i žrtva krivičnog dela, kao što je } \\
\text { na primer slučaj sa osuđenicama koje su osuđene } \\
\text { zbog ubistva svog zlostavljača. } \\
\end{array}$ \\
\hline $\begin{array}{c}\text { Obeštećenje žrtve obično podrazumeva naknadu štete, } \\
\text { materijalnu, ali ono može biti i simbolično te se realizovati } \\
\text { na primer, kroz izvinjenje, prihvatanje odgovornosti za } \\
\text { nanetu štetu (viktimizaciju). }\end{array}$ & $\begin{array}{l}\text { U restorativnom performansu osuđenih lica ne } \\
\text { ostvaruje se obeštećenje žrtve u materijalnom smislu, } \\
\text { već se ono realizuje na simboličan način i to tako što, } \\
\text { u zavisnosti od sadržine samog performansa (koja je } \\
\text { po pravilu takva da odgovara i ovom cilju), učinilac } \\
\text { kroz performans priznaje svoje delo, prihvata svoju } \\
\text { odgovornost za njega i javno izražava kajanje. }\end{array}$ \\
\hline Vraćanje duga zajednici & $\begin{array}{c}\text { Mogućnost za prestupnike da kroz pozorišni } \\
\text { performans učine nešto dobro i lepo za publiku kao } \\
\text { oličenje zajednice, da joj kroz umetnički izraz podare } \\
\text { delić duhovnosti, osećajnosti }\end{array}$ \\
\hline Osnaživanja učesnika & $\begin{array}{c}\text { Osnaživanje kroz obrazovanje putem pozorišta, kao i } \\
\text { emotivno osnaživanje }\end{array}$ \\
\hline $\begin{array}{l}\text { Restorativna pravda često se opisuje kao proces, imajući u } \\
\text { vidu da kod nje veći značaj ima sam postupak izmirenja i } \\
\text { obeštećenja nego njegov krajnji cilj }\end{array}$ & $\begin{array}{c}\text { Performans se definiše kao proces, u smislu da je kod te } \\
\text { vrste umetnosti mnogo važniji sam proces izvođenja nego } \\
\text { neki krajnji produkt/cilj koji se njime ostvaruje }\end{array}$ \\
\hline
\end{tabular}

\section{METODOLOŠKI OKVIR ISTRAŽIVANJA}

Za teorijsku analizu pojma restorativne pravde i pozorišnog performansa korišćeni su: metod jezičkog tumačenja i deskriptivni metod, dok je za potrebe definisanja pojma restorativne pravde $\mathrm{u}$ skladu sa međunarodnim dokumentima korišćen normativni metod. Za prikupljanje podataka na kojima se temelje rezultati istraživanja prezentovani u ovom radu korišćeni su sledeći metodi: posmatranje, polustruktuisani intervju, fokus grupni intervju i fotografisanje.

Posmatranje (Lakićević, Knežić, 2011:127-131) je primenjeno kao metoda prikupljanja podataka tokom izvođenja pozorišnih performansa analiziranih u ovom radu. To su sledeći pozorišni performansi: 1) „Zapisi iz ćelije broj 12“, 2) „Njena priča“, 3) Performans „Pravila kluba boraca“ izveden prilikom premijere dokumentarnog filma „Komanda ljubav“ i 4) „O bogovima, herojima i ostalim vitezovima“. Posmatranje je sprovedeno na sledeči način i pod sledećim 


\section{Zbormik IKSI, 1/2021 - A. Batrićević, M. Kovačević \\ „Restorativni performans i resocijalizacija osuđenih lica”, (str. 25-49)}

okolnostima. MA Marina Kovačević, koautorka ovog rada, osnivačica i direktorka Instituta za performativne umetnosti i socijalni rad je samostalno, neposredno radila sa osuđenim licima na svakom segmentu pripreme i izvođenja svih performansa analiziranih u ovom radu. MA Marina Kovačević je lično vodila radionice kreativnog pisanja za osuđena lica prilikom kojih su stvarani scenariji za pomenute performanse, kao i za pomenuti dokumentarni film. Osim toga, MA Marina Kovačević je lično rukovodila pripremama i probama pomenutih performansa - od odabira učesnika pa do samog izvođenja na sceni, te je, u svakoj od navedenih prilika primenila metod neposrednog posmatranja. Osim toga, dr Ana Batrićević, takođe koautorka ovog rada lično je prisustvovala premijernoj i ponovljenoj izvedbi pozorišne predstave „O bogovima, herojima i ostalim vitezovima“ $\mathrm{i}$ fotografisala obe izvedbe, tako da je i ona tom prilikom primenila metod neposrednog posmatranja, dok se sa sadržinom ostalih upoznala metodom posrednog posmatranja - putem gledanja video snimaka izvođenja analiziranih performansa, koji su dostupni na linkovima navedenim u referencama ovog rada.

Dubinski polustruktuisani intervju (Lakićević, Knežić, 2011: 108-111) i fokus grupni intervjui (Đurić, 2007: 19-25) primenjeni su za prikupljanje podataka o utiscima, osećanjima i stavovima učesnika u pozorišnim performansima. Dubinske polustruktuisane intervjue i fokus grupne intervjue sa osuđenim licima koja su učestvovala $\mathrm{u}$ performansima analiziranim $\mathrm{u}$ ovom radu sprovodila je lično $\mathrm{i}$ samostalno MA Marina Kovačević i to tokom pripremanja i nakon izvođenja istih. Dakle, ovaj segment istraživanja pratio je pripremanje i izvođenje svakog od pomenutih performansa, odvijajući se paralelno sa njima. Kao što je već istaknuto, pripremanje i izvođenje pomenutih performansa realizovala je MA Marina Kovačević, ispred Instituta za performativne umetnosti i socijalni rad, a uz podršku Udruženja građana HELP i misije OEBS-a u Srbiji. Istraživanje utisaka, osećanja i stavova učesnika analiziranih performansa putem dubinskih polustruktuisanih i fokus grupnih intervjua MA Marina Kovačević sprovela je za potrebe svog Instituta za performativne umetnosti i socijalni rad, a u svrhu praćenja napredovanja osuđenih lica sa kojima je radila i ostvarivanja boljeg i potpunijeg uvida u efekte ove vrste rada na njih.

1) „Zapisi iz ćelije broj 12“ pripremani su od kraja 2013. godine do kraja 2015. godine u Okružnom zatvoru u Beogradu. Performans je izveden ukupno 17 puta, a od toga 5 puta u ustanovama za izvršenje krivičnih sankcija u Srbiji. U njem je učestvovalo 20 osuđenika. MA Marina Kovačević je u pomenutom periodu sprovela polustruktuisane i dubinske polustruktuisane intervjue sa svih 20 učesnika.

2) „Njena priča“ pripremana je od početka 2017. godine do kraja 2018. godine u Kazneno-popravnom zavodu za žene u Požarevcu i izvedena u dva navrata u toj ustanovi 21. 12. 2018. i 26. 12. 2018. godine. U performansu je učestvovalo ukupno 12 osuđenica. MA Marina Kovačević je u pomenutom periodu sprovela polustruktuisane i dubinske polustruktuisane intervjue sa svih 12 učesnica.

3) Performans „Pravila kluba boraca“ izveden prilikom premijere dokumentarnog filma „Komanda ljubav“. Performans i dokumentarni film pripremani su od marta 2018. do decembra 2019. godine u Kazneno-popravnom zavodu u Sremskoj 


\section{Zbornik IKSI, 1/2021 - A. Batrićević, M. Kovačević \\ „Restorativni performans i resocijalizacija osuđenih lica”, (str. 25-49)}

Mitrovici, a izvedeni su 15. 03. 2019. godine u Domu omladine u Beogradu. U performansu „Pravila kluba boraca“ je učestvovalo 6 osuđenika a u dokumentarnom filmu njih 15. MA Marina Kovačević je u pomenutom periodu sprovela polustruktuisane i dubinske polustruktuisane intervjue sa svih 6 , odnosno 15 , što ukupno čini 21 učesnika.

4) „O bogovima, herojima i ostalim vitezovima“ pripreman je u periodu od početka 2019. do početka 2020. godine u Vaspitno-popravnom domu za maloletnike u Kruševcu. Izveden je u dva navrata: U performansu je učestvovalo ukupno 20 štićenika. MA Marina Kovačević je u pomenutom periodu sprovela polustruktuisane i dubinske polustruktuisane intervjue sa svih 20 štićenika.

Fotografisanje (više o tome: Langman, Pick, 2018) je primenjeno kao metod prikupljanja podataka, tako što su dokumentarnim fotografijama zabeležene najupečatljivije scene iz pozorišnih performansa obuhvaćenih ovim istraživanjem kako bi se i vizualno dočarala njihova restorativna simbolika. Prikupljeni podaci analizirani su primenom: sekundarne analize i analize sadržaja dokumenata, kao i studijom slučaja. Sekundarna analiza (Mimica, Bogdanović, 2007: 15) primenjena je kako bi se analizirali tekstovi o dosadašnjim primerima programa resocijalizacije prestupnika kroz umetnost uopšte, a posebno kroz pozorišni performans, dok je kvalitativna analiza sadržaja (Manić, 2017:46-51) primenjena na proučavanje fotografija i video zapisa napravljenih prilikom izvođenja pozorišnih performansa analiziranih u ovom radu, kao i sadržaja koji su nakon njihovog izvođenja objavljeni u pisanim i štampanim medijima. Metod studije slučaja (Ševkušić, 2008: 240-243) primenjen je na analizu programa rada tokom koji su pomenuti pozorišni performansi pripremani.

\section{RESTORATIVNI PERFORMANS, FILMSKA UMETNOST I RESOCIJALIZACIJA PRESTUPNIKA - PRIMERI DOBRE PRAKSE U SRBIJI}

\subsection{Pozorišna predstava "Zapisi iz ćelije broj 12"}

U predstava "Zapisi iz ćelije broj 12" pripremana je sa osuđenicima Okružnog zatvora u Beogradu, kao svojevrsni omnibus književnih dela, koji u monološkoispovednom tonu sublimira različite aspekte ropstva i slobode. 4 Prvi čin predstave je dramatizacija književnih dela F. M. Dostojevskog: „Zapisi iz mrtvog doma“ (1862), koje prikazuje život zatvorenika u Sibiru, i „Zapisi iz podzemlja“ (1864), koje sadrži intimnu filozofsku ispovest čoveka „iz podzemlja“, izolovanog od sveta i društva. Dela su prilagođena sadašnjem vremenu i stvarnosti koja okružuje izvođače prestave, a autorka scenarija je MA Marina Kovačević. Drugi čin predstavlja

\footnotetext{
4 Više o tome: Intervju - Marina Kovačević, CRI: "Osuđenici ne glume, oni žive taj život“, Dom omladine Beograda, 03.09.2015., dostupno na: https://domomladine.org/intervju-marinakovacevic-cri-osudjenici-ne-glume-oni-zive-taj-zivot/, stranici pristupljeno 29.03.2021.
} 


\section{Zbornik IKSI, 1/2021 - A. Batrićević, M. Kovačević \\ „Restorativni performans i resocijalizacija osuđenih lica”, (str. 25-49)}

autorsko delo osuđenika Đorđa Vasiljevića, nosioca jedne od dve glavne uloge u predstavi, gde je na osnovu sopstvenog iskustva, prikazao inicijaciju novopridošlog mladića u strogu zatvoreničku subkulturu, koja se odvija iza zidova ćelije, daleko od očiju stražara, a od koje zavisi njegov dalji opstanak u okruženju kojem ne pripada (Vasiljević, 2018: 309-319).

Ideja predstave bila je da osuđenici kroz pozorišnu igru, konkretizujući problem iz uloge koja im omogućava da se izmeste u drugi svet, lakše sagledaju svet sa distance, da 'isprobaju' drugačije postavke i da ispolje svoja osećanja. Predstava je istovremeno i sublimacija ličnog istraživanja pojedinaca - aktera, ali i zajednički fokus ove pozorišne grupe oko jedne pojave, koji im omogućava da se slobodno i kreativno izraze. 5 Istoimeni dokumentarni film prati proces početka i razvijanja ove pozorišne predstave u periodu njenog nastanka i izvođenja 2014-2015. godine. ${ }^{6}$ Predstava je prikazana u sledećim ustanovama za izvršenje krivičnih sankcija u Srbiji: Kazneno-popravnom zavodu u Požarevcu Zabeli (28.04.2015.), Kaznenopopravnom zavodu u Nišu (26.05.2015.), Okružnom zatvoru u Novom Sadu (19.06.2015.), u Specijalnoj zatvorskoj bolnici u Beogradu (15.07.2015.), u Kaznenopopravnom zavodu u Sremskoj Mitrovici (01.09.2015.) i, na kraju, u velikoj Sali Doma omladine Beograda, pred preko 500 gledalaca, koji su čak 10 minuta aplaudirali glumcima na kraju predstave (07.09.2015.) ${ }^{7}$.

\footnotetext{
5 Pozorišna predstava "Zapisi iz ćelije broj 12", CRI (Centar za rehabilitaciju imaginacijom) Institut za performativne umetnosti i socijalni rad, dostupno na:https://cri.edu.rs/sr/pozorisna-predstavazapisi-iz-celije-broj-12/, stranici pristupljeno 01.03.2021. ${ }^{6}$ Dokumentarni film "Zapisi iz ćelije br. 12", dostupno na: https://www.youtube.com/watch?v=1fK2DJuC8To, stranici pristupljeno 01.03.2021. 7 Dnevnik sa turneje "Zapisa iz ćelije br. 12", po ustanovama za izvršenje krivičnih sankcija i ustanovama kulture, dostupno na: https://cri.edu.rs/sr/zapisi-iz-celije-broj-12/, stranici pristupljeno 09.03.2021.
} 


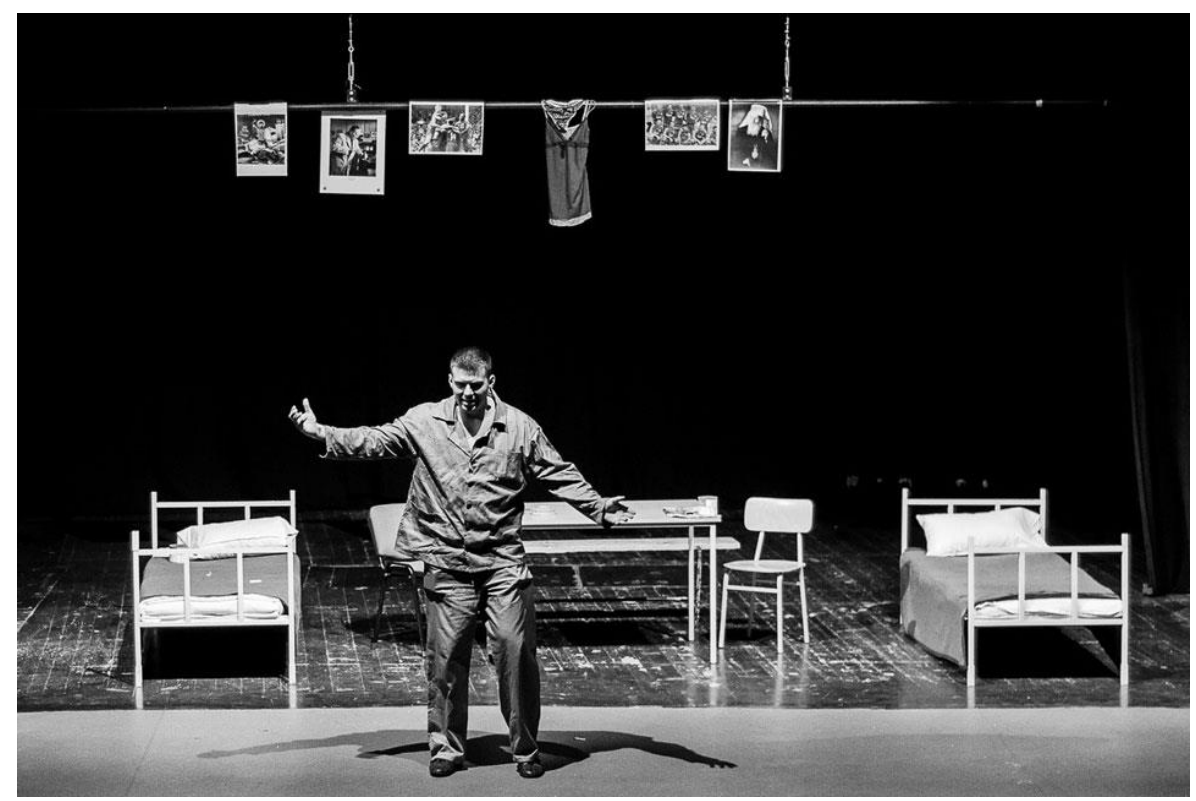

Fotografija 1: Pozorišna predstava “Zapisi iz ćelije broj 12”, Dom omladine Beograda, 07.09.2015. Autor: Igor Čoko

\subsection{Pozorišna predstava „Njena priča“}

Predstava „Njena priča“ nastala je na radionicama kreativnog pisanja za osuđenice u Kazneno-popravnom zavodu za žene u Požarevcu ${ }^{8}$, tokom kojih su one imale mogućnsot da svoja osećanja izraze kroz literarne radove te da se na taj način emotivno iscele i osnaže. U radionicama i predstavi učestvovalo je ukupno 12 osuđenica. Svaka od njih je pre dolaska na izdržavanje kazne bila izložena nekom obliku nasilja. Njih 10 bilo je osuđeno upravo zbog ubistva svojih zlostavljača muževa, makroa i zeta, dok je dvema kazna zatvora izrečena zbog privrednog kriminaliteta. Sve osuđenice su ispoljile neverovatnu motivisanost za pisanje i glumu, a zajednički kreativni rad ih je zbližio.

Protagonistkinja je žena - žrtva nasilja u porodici koja sanja da pokušava da ubije svog supruga - zlostavljača, ali se tada pojavljuje ostalih 11 osuđenica koje u poslednjem trenutku uspevaju da je od toga odvrate. One joj upućuju reči utehe, nagovaraju je da se umesto činjenja krivičnog dela obrati za pomoć, grle je i hrabre. Ona se budi i odlučuje da to ni u stvarnosti ne učini, već da zlostavljača napusti i potraži pomoć i podršku. Poruka je jasna - da „tama ne može oterati tamu“, i da upravo zajednica odnosno društvo i država treba da blagovremeno

${ }^{8}$ Radionice i predstava realizovane su u okviru projeka koji je podržala organizacija HELP-Hilfe zur Selbsthilfe. 


\section{Zbormik IKSI, 1/2O21 - A. Batrićević, M. Kovačević \\ „Restorativni performans i resocijalizacija osuđenih lica”, (str. 25-49)}

reaguju u slučajevima nasilja nad ženama, da one dobiju pomoć, podršku i zaštitu a ne da moraju same da se štite tako što će izvršiti krivično delo i od žrtve postati osuđenice.

Njena priča izvedena je dva puta krajem 2018. godine - pred osuđenicama iz zatvorenog i pred onima iz poluotvoreng bloka, naišavši na izuzetno emotivan i topao prijem - osuđenice su plakale, identifikovale su se sa izvođačima i saosećale sa njima. Osuđenica koja je igrala glavnu ulogu, u stvarnosti je postupila upravo onako kako je glavna junakinja zamalo učinila u snu. Zato je za nju ovo izvođenje imalo poseban emotivni značaj jer je kroz njega na jedan simboličan način ispravila svoju grešku iz prošlosti. Upravo taj momenat može biti bitan za sprečavanje povrata, premda je ovde reč mahom o situacionim izvršiteljkama, dakle ženama koje nemaju kriminalnu prošlost, već su samo u odsustvu blagovremen pomoći kada su one bile žrtve, izvršile krivično delo i bile osuđene.

I na ostale osuđenice učestvovanje u samom procesu pripremanja i izvođenja predstave, delovalo je oslobađajuće, pomogavši im da prevaziđu inicijalnu tremu i stid zbog pojavljivanja pred zajednicom nakon onoga što su učinile i da se osete prihvaćeno i osnaženo. U tom smislu, "Njena priča" osobito naglašava princip reintegrativnog postiđivanja, kao jednog od najznačajnijih elemenata restorativnog procesa, ali, svakako i ostale njegove principe, kao što je osnaživanje, praštanje...

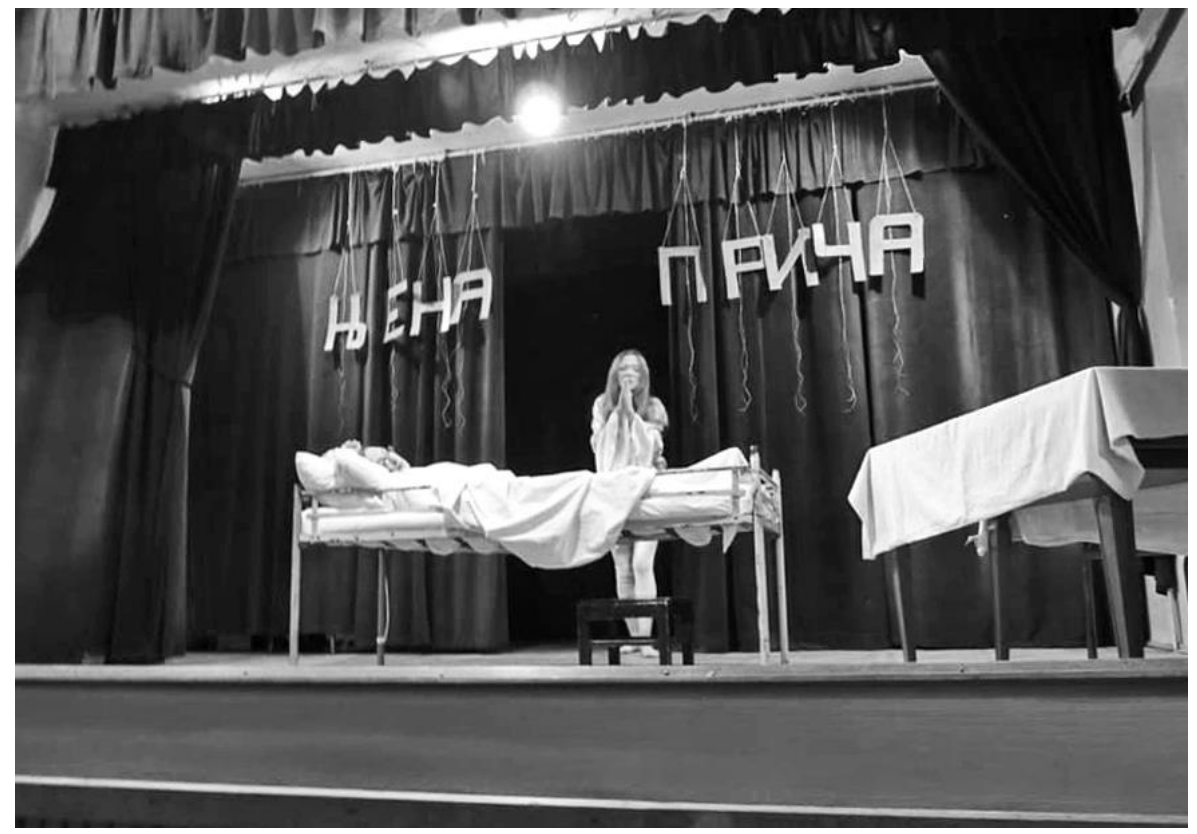

Fotografija 2: Pozorišna predstava "Njena priča", Kazneno-popravni zavod za žene u Požarevcu, 26. 12. 2018. Autor: Uprava za izvršenje krivičnih sankcija 


\author{
Zbornik IKSI, 1/2021 - A. Batrićević, M. Kovačević \\ „Restorativni performans i resocijalizacija osuđenih lica”, (str. 25-49)
}

\title{
4.3. Dokumentarni film „Komanda ljubav“ \\ i performans „Pravila kluba boraca“
}

Dokumentarni film "Komanda ljubav" govori o rehabilitaciji osuđenika kroz rad i interakciju sa psima iz azila u kazneno-popravnom zavodu u Sremskoj Mitrovici ${ }^{9}$ Rehabilitacija osuđenih lica se odvija u dva plana, kroz učenje komandi potrebnih u treningu dresure i kroz kreativno pisanje. Film prikazuje program rada osuđenika sa psima, ali priča paralelno prati lični, emotivni odnos i doživljaj koji kroz kreativno pisanje osuđenici ostvaruju sa psima. Specifičnost ovog programa jeste u kreativnom pisanju dnevnika, poetskoj verbalizaciji osećanja koja ostvaruju sa bićima o kojima osuđenici brinu ${ }^{10}$. Dobre strane ovog programa su višestruke - kako za sama osuđena lica, kod koji se jača osećanje empatije, odgovornosti za druge, ali i povećava zapošljivost po izlasku na slobodu, tako i za životinje, koje nakon dresure i savladavanja osnovnih komandi lakše pronalaze novi dom, i, konačno, u duhu restorativnog procesa, za celokupnu zajednicu koja osim rešavanja problema napuštenih pasa, može očekivati i smanjenje stope kriminaliteta zahvaljujući ovom programu (Batrićević, 2019: 9-10).

Na premijeri dokumentarnog filma „Komanda ljubav“ u Domu omladine Beograda 14.03.2019. šest osuđenika je nakon projekcije samog filma izvelo i performans „Pravila kluba boraca“ koji je rađen po uzoru na američki film „Borilački klub“ (Fight Club) iz 1999. godine, u režiji Dejvda Finčera, zasnovan na istoimenom romanu Čaka Polanika iz 1996. Ovaj performans čini specifično koncipirana desetominutna pokazna vežba rada sa psima, prilikom koje je svaki osuđenik u poetskom iskazu demonstrirao po jedno pravilo ljubavi koje treba primeniti u dresuri pasa. Reakcije medija i šire javnosti na na ovaj program i njegov umetnički prikaz bile su izuzetno pozitivne, što je i osuđenim licima predstavljalo ogroman podstrek za dalji rad na sebi.

\footnotetext{
9 Dokumentarni film Komanda ljubav, dostupno na:https://www.youtube.com/watch?v=IYPgzlCNh4, stranici pristupljeno 01.03.2021.

${ }^{10}$ Ovaj projekat je ostvaren u saradnji između KPZ-a, grada Sremska Mitrovica, misije OEBS-a u Srbiji, Uprave za izvršenje krivičnih sankcija Ministarstva pravde Republike Srbije i nemačke nevladine organizacije Help.
} 


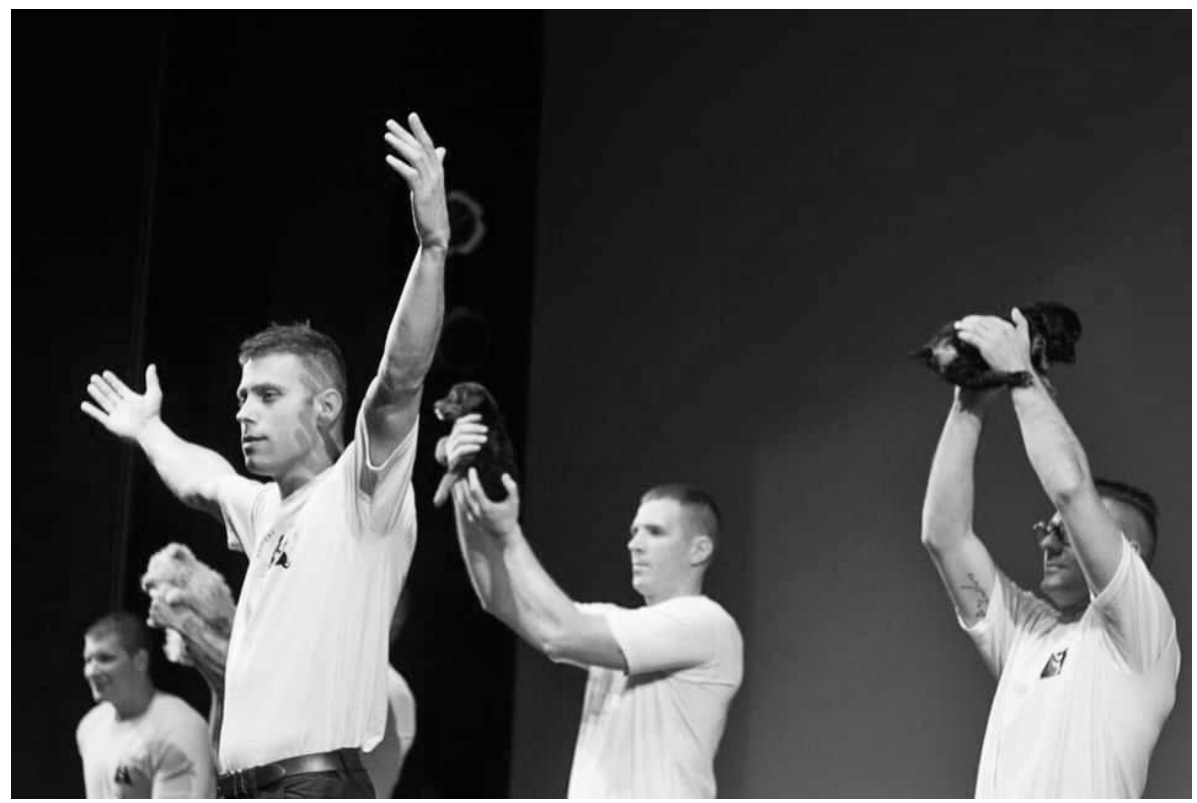

Fotografija 3: Premijera dokumentarnog filma "Komanda ljubav“, Dom omladine Beograda, 14.03.2019. Autor: Igor Čoko

\subsection{Pozorišna predstava „O bogovima, herojima i ostalim vitezovima“}

Pozorišna predstava sa štićenicima Vaspitno-popravnog doma u Kruševcu „O bogovima, herojima i ostalim vitezovima" nastala na radionicama kreativnog pisanja, izvedena je premijerno u Vaspitno-popravnom domu u Kruševcu, a potom i u Domu omladine Beograda. Štićenici su na radionicama imali priliku da verbalizuju osećanja, pišu poeziju, da upoznaju grčke mitove, odaberu najinteresantnije za proučavanje i intervenišu na njivom sadržaju.

Radionice kreativnog pisanja su pružile štićenicima mogućnost da ispolje maštu i osećanja, da utiču na mitove, osmišljavajući drugačiji kraj i to s porukom kako rešiti sukob između dobra i zla. Pored igranja kroz glumu, oni menjaju karaktere junaka, uče o životu, ispravljaju sudbine koje u njihovom izvođenju nisu tragične, što je poruka za njihov stvarni život - srećan kraj je moguć i mi ga stvaramo. ${ }^{11}$

Oba izvođenja predstave omogućila su učesnicima da kroz jedinstveni performans iskažu svoja osećanja i prenesu poruku zajednici da je moguće slediti prave

${ }^{11}$ Sivi dom ulepšan umetnošću, Politika, 10.05.2020., dostupno na: http://www.politika.rs/scc/clanak/453842/Sivi-dom-ulepsan-umetnoscu, stranici pristupljeno 03.01.2021. 


\section{Zbornik IKSI, 1/2021 - A. Batrićević, M. Kovačević \\ „Restorativni performans i resocijalizacija osuđenih lica”, (str. 25-49)}

vrednosti, izaći na dobar put uprkos preprekama i pritiscima sredine te da od njih samih, ali i podrške društva zavisi da li će kraj biti srećan. O podršci zajednice govori izuzetno pozitivan prijem ove predstave, kako u medijima i tako i kod publike.

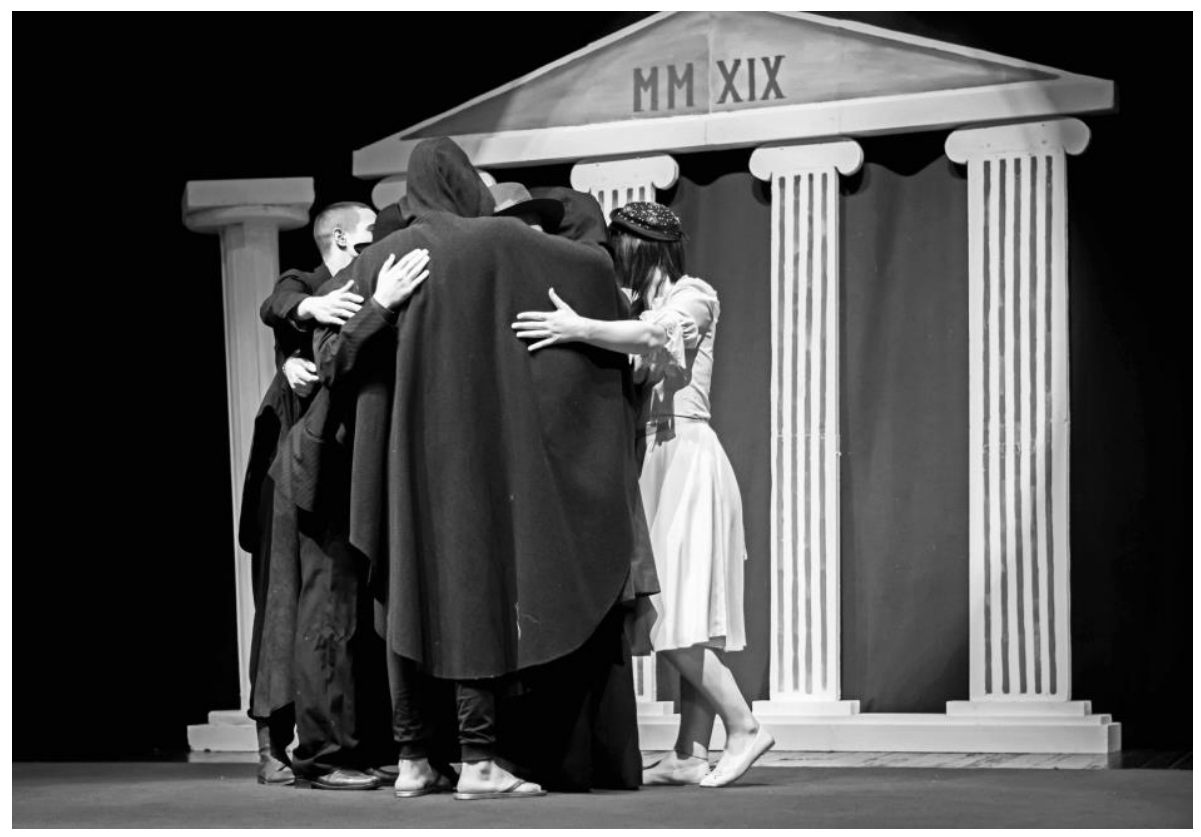

Fotografija 4: Pozorišna predstava "O bogovima, herojima i ostalim vitezovima", Dom omladine Beograda, 11.12.2019. Autor: Ana Batrićević

\section{RESTORATIVNI EFEKTI PERFORMANSA OSUĐENIH LICA U SRBIJI - ANALIZA REZULTATA ISTRAŽIVANJA}

Proces pripremanja, sadržina i način izvođenja performasa osuđenih lica analiziranih u ovom radu, kao i ciljevi koji se njima nastoje realizovati približavaju ih restorativnom procesu, a i efekti koje su oni proizveli kako na osuđena lica koja su u njima učestvovala, tako i na publiku kao oličenje zajednice, govore u prilog tome da im se može dodeliti epitet „restorativnih“. U skladu sa tim, restorativni elementi koji ih prožimaju analizirani su ovde po fazama: počevši od pripreme performansa, preko njihovog izvođenja pred publikom pa do perioda koji je potom usledio.

Pojedini restorativni elementi ispoljili su se u određenoj meri već u fazi pripremanja svakog od analiziranih performansa - na radionicama kreativnog pisanja. Reč je o: priznanju izvršenja krivičnog dela, pokajanju i osnaživanju, s tim što treba naglasiti da su oni u ovoj fazi ispoljeni samo delom, da bi u potpunosti došli do izražaja tek 
prilikom izvođenja, o čemu ce posebno biti reči, jer na radionicama kreativnog pisanja nije bila prisutna javnost u smislu publike već je ona samo delimično bila predstavljena u liku voditeljke radionica i osuđenih lica koja su u njima učestvovala. U ovoj fazi, priznanje krivičnog dela pred ostalim učesnicima i voditeljkom radionica dolazilo je mahom spontano. Učesnicima nisu nametnuta takva pitanja i teme, već su oni sami, kroz kreativno pisanje i razgovore u određenim momentima osećali potrebu da se dotaknu razloga i okolnosti usled kojih su dospeli na izdržavanje kazne. Priznanje je najčešće bilo praćeno iskrenim pokajanjem na strani učesnika, što je takođe bitna odlika restorativnih procesa, kao i njihovom željom da makar kroz svoje literarne radove ponovo prožive sopstvenu prošlost $i$ isprave greške koje su napravili, kao i da utiču na druge da u sličnim situacijama postupe ispravno.

Već u ovoj fazi, otpočelo je i osnaživanje učesnika i to na dva nivoa: intelektualnom i emotivnom. Intelektualno osnaživanje ostvareno je putem usvajanja novih znanja i veština kroz čitanje književnih dela i pisanje literarnih radova. Intelektualno osnaživanje nastavljeno je i tokom pripremanja izvedbi - na probama, kada su mnogi od učesnika po prvi put otkrili sopstveni kreativni potencijal, što se pozitivno odrazilo na njihov odnos prema sebi, bližnjima, široj okolini, ali i prema obrazovanju, radu i planovima u vezi sa životom na slobodi. Uviđanje da su sposobni i talentovani da rade lepe i korisne stvari ulivalo je učesnicima elan, samopouzdanje, samopoštovanje i želju da u budućnosti žive ispravno, kao korinsi članovi zajednice. Drugi vid osnaživanja - emotivno osnaživanje učesnika realizovano je kroz njihov razgovor i pisanje o sopstvenim osećanjima, koja su neki tada po prvi put podelili sa drugima, što je na njih, prema njihovim priznanjima, imalo snažan isceljujući efekat. To se naročito odnosi na osuđenice koje su učestvovale u pozorišnom performansu „Njena priča“, a koje su istovremeno bile i žrtve nasilja.

U fazi samog izvođenja analiziranih performansa takođe se, $\mathrm{u}$ još većoj meri, zahvaljujući prisustvu i podršci publike, ispoljavaju restorativni elementi. Pre svega, svi oni su izvedeni javno, pred publikom, koja je upravo oličenje zajednice, kao ključne od zainteresovanih strana u restorativnom procesu. Naravno, to ni u kom slučaju ne znači da je svaki javni performans automatski i restorativan, ali, u slučaju performansa osuđenih lica, pri čemu publika zna da su u pitanju učinioci krivičnih dela, prisustvo i podrška javnosti ima veliki restorativni značaj. Upravo taj izlazak pred publiku, u kojoj su često bili i članovi njihovih porodica, prijatelji, ostali osuđenici, predstavnici pravosudnih organa i Uprave za izvršenje krivičnih sankcija, ali i drugi, učesnicima nepoznati, „obični“ građani element je restorativnog procesa. Osim prisustva, zajednica je kroz aplauz i neskriveno oduševljenje publike simbolično iskazala učesnicima svoju podršku, razumevanje i prihvatanje što je, prema rečima osuđenih lica, takođe imalo restorativan, osnažujuć efekat na njih. Prema njihovim rečima, afirmacija od strane publike učinila je da se osećaju sposobno da čine dobre i korisne stvari, podstakla je u njima želju da se nakon izlaska na slobodu reintegrišu u zajednicu i učvrstila njihovu odluku da se ne vrate kriminalnom modelu ponašanja. Publika je znala da su u pitanju osuđenici, a opet je došla, da čuje njihov glas, da sa njima podeli deo stvarnosti, ih razume i podrži.

Priznanje krivičnog dela od strane prestupnika u ovoj fazi dobija svoj pun smisao jer je potpuno javno, a ono se ostvaruje kroz samu sadržinu performansa, jer je njihova 
tematika uglavnom takva da se izvođači makar u nekom momentu dotiču teme krivice, krivičnog dela, kazne, lišenja slobode, aludirajući na sopstvenu životnu situaciju. Načinom na koji učesnici o tome govore na sceni oni jasno pokazuju kajanje i želju da se pred čitavim društvom iskupe za svoju prošlos, što je delom simbolizovano i kroz naklon na kraju predstave, koji je ovde mnogo više od puke pozorišne formalnosti. Većina učesnika je posvedočila da su tokom izvođenja, uvidevši da ostvaruju kontakt i razmenu emocija sa publikom kojoj priznaju svoje delo i pred kojom izražavaju kajanje, osetili neku vrstu emotivne katarze pročišćenja, oslobođenja i olakšanja.

Posmatrano sa aspekta zajednice, odnosno javnosti, takođe su ostvareni određeni restorativni elementi. U prilog tome govore detaljno analizirani izveštaji medija o svakom od navedenih performansa, koji su u svakom smislu bili pozitivni. To implicira da je zajednica pokazala spremnost da učesnicima pruži drugu šansu, odnosno da ih ponovo prihvati kao svoje ravnopravne članove. Na taj način, omogućeno im je da na jedan simboličan način, darujući zajednici svoje umetničko izvođenje, pokažu spremnost da vrate svoj dug društvu, što je ono prihvatilo otvorenog srca.

\section{ZAKLJUČAK}

Teorijska analiza restorativnog procesa, sa jedne i performansa, sa druge strane, otkriva niz dodirnih tačaka između ova dva pojma. Njihova bliskost dolazi do izražaja u situacijama kada se performans realizuje u specifičnom kontekstu - kada su njegovi učesnici učinioci i/ili žrtve krivičnih dela, a publika oličenje društva, odnosno šire zajednice. Pod takvim okolnostima, a u zavisnosti od same sadržine performansa, ovaj oblik umetničkog izražavanja može poprimiti restorativni karakter, u smislu kako je to definisano kod restorativnih procesa.

Imajući u vidu dosadašnju uspešnu primenu umetnosti u svrhu socijalne reintegracija osuđenih lica, uvođenje pojma restorativnog performansa u teoriju i praksu, čini se sasvim opravdanim. U pitanju je veoma osoben oblik umetničkog izražavanja koji se po svojim, učesnicima i uslovima izvođenja razlikuje od ostalih umetničkih performansa, dok mu restorativni ciljevi i efekti daju dodatni kvalitet. Uvođenje ovog pojma u teoriji otvorilo bi prostor za širu afirmaciju i primenu restorativnog performansa kao inovativnog metoda rada sa osuđenim licima u praksi. Istovremeno, time bi se doprinelo koncipiranju jedinstvenih programa rada sa osuđenim licima, praćenje njihovog sprovođenja i efekata kako na aktuelno stanje, ponašanje, osećanja učesnika, tako i na uspešnost resocijalizacije, odnosno stepen recidivizma (kroz longitudinalna istraživanja).

Nedovoljna senzitivisanost javnosti i oskudna podrška nacionalnih i lokalnih medija za umetničke projekte odražava se i na primenu takvih inicijativa u oblasti izvršenja krivičnih sankcija (Farrier, Froggett, Poursanidou, 2009: 62). Zato je neophodno uticati na podizanje svesti relevantnih aktera o kapacitetima restorativnog performansa da doprinese smanjenju zatvorskih deprivacija i osećaja represiranosti, ali i uspešnosti resocijalizacije i socijalne reintegracije osuđenih lica i smanjenju 


\author{
Zbornik IKSI, 1/2021 - A. Batrićević, M. Kovačević \\ „Restorativni performans i resocijalizacija osuđenih lica”, (str. 25-49)
}

recidiva. Izuzetno je važno promovisati ovakve programe rada u zajednici, budući da ona čini ključnu komponentu restorativnog procesa te da bez njenog učešća i podrške on ne može biti potpun. U tom smislu, senzitivizacija ne samo naučne i stručne javnosti već i svih građana na ovu temu putem naučnih publikacija, ali i medija i društvenih mreža neophodan je korak ka upotpunjavanju kruga podrške i otpočinjanju restorativnog procesa osnaženog transformativnim dejstvom umetnosti.

\title{
REFERENCE
}

(1) Batrićević, A. (2019) Druga šansa: rad osuđenika sa psima u KPZ Sremska Mitrovica. Beograd: Institut za kriminološka i sociološka istraživanja.

(2) Czuba, C. E., \& Page, N. (1999). Empowerment:What is it? Journal of Extension, $37(5)$, str. 1-5.

(3) Dimovski, D. (2012) Politika suzbijanja homicida. Zbornik radova Pravnog fakulteta u Nišu, 63(1), str. 363-373.

(4) Dnevnik sa turneje "Zapisa iz ćelije br.12" po ustanovama za izvršenje krivičnih sankcija i ustanovama kulture, dostupno na: https://cri.edu.rs/sr/zapisi-iz-celijebroj-12/, stranici pristupljeno 09.03.2021.

(5) Dokumentarni film Komanda ljubav , dostupno na: https://www.youtube.com/watch?v=IYPg-zlCNh4, stranici pristupljeno 01.03.2021.

(6) Dokumentarni film "Zapisi iz ćelije br. 12", dostupno na: https://www.youtube.com/watch?v=1fK2DJuC8To, stranici pristupljeno 01.03.2021.

(7) Farrier, A., Froggett, L., \& Poursanidou, D. (2009) Offender-based Restorative Justice and Poetry:Reparation or Wishful Thinking? Youth Justice, 9(1), str. 61-76. https://doi.org/10.1177/1473225408101432

(8) Fischer-Lichte, E. (2009) Estetika performativne umjetnosti. Sarajevo-Zagreb: Šahinpašić.

(9) Freire, P. (2005) Pedagogy of the Oppressed - $30^{\text {th }}$ anniversary edition. New York: Continuum.

(10) Ćopić, S. (2007) Pojam i osnovni principi restorativne pravde. Temida, 1O(1), str. 25-35.

(11) Ćopić, S. (2015) Restorativna pravda i krivičnopravni sistem: teorija, zakonodavstvo i praksa. Beograd: Institut za kriminološka i sociološka istraživanja.

(12) Ćopić, S., \& Nikolić-Ristanović, V. (2018) Podizanje svesti osuđenih lica o restorativnoj pravdi i žrtvama:Primer programa sprovedenog u zatvoru za žene u Srbiji. Temida, 21(3), str. 385-410. https://doi.org/10.2298/TEM1803385C

(13) Dzur, A.W., \& Wertheimer, A. (2002) Forgiveness and public deliberation: The practice of restorative justice. Criminal Justice Ethics, 21(1), str. 3-20. https://doi.org/10.1080/0731129X.2002.9992112

(14) Đorović, U., Matošević, J., Milošević, L., Nikolić, M., \& Romanov, V. (2020) Potrebe i izazovi bivših osuđenih lica u procesu resocijalizacije i reintegracije - iskustva udruženja građana „Posle kiše“ iz Kragujevca. Zbornik Instituta za kriminološka $i$ sociološka istraživanja, 39(2-3), str. 9-26. https://doi.org/10.47152/ziksi2020231

(15) Đurić, S. (2007) Fokus-grupni intervju. Beograd: Službeni glasnik.

(16) Fiske, E. (ed.) (1999) Champions of Change: the Impact of the Arts on Learning. Washington DC: Arts Education Partnership, dostupno na: https://eric.ed.gov/?id=ED435581, stranici pristupljeno 16.03.2021. 


\author{
Zbornik IKSI, 1/2021 - A. Batrićević, M. Kovačević \\ „Restorativni performans i resocijalizacija osuđenih lica”, (str. 25-49)
}

(17) Gjaerum, R. G. (2014) Applied Theatre Research:Discourses in the Field. European Scientific Journal, 9(10), str. 347-361.

https://doi.org/10.19044/esj.2013.v9n10p\%p

(18) Hartley, J.S. (2012) Applied Theatre in Action:A Journey. Stoke-on-Trent, UK: Trentham Books.

(19) Hausmann,C., Jonason, A., \& Summers-Effler, E. (2011) Interaction Ritual Theory and Structural Symbolic Interactionism. Symbolic Interaction, 34(3), str. 319-329. https://doi.org/10.1525/si.2011.34.3.319

(20) Ignjatović, Đ. (2017) Kazneni populizam, u: Ignjatović, Đ. (ur.) Kaznena reakcija u Srbiji (VII deo). Beograd:Univerzitet u Beogradu - Pravni fakultet, str. 11-32.

(21) Ilijić, Lj. (2012) Adaptacija na zatočeništvo.Zbornik Instituta za kriminološka i sociološka istraživanja, 31(1), str. 231-240.

(22) Ilijić, Lj. (2014) Osuđeni i deprivacije - uticaj karakteristika ličnosti na intenzitet doživljavanja zatvorskih deprivacija. Beograd: Institut za kriminološka i sociološka istraživanja.

(23) Ilić, A. (2011) Prenaseljenost zatvora - fenomenološki i etiološki aspekti. Crimen, 2(2), str. 245-256.

(24) Ilić, V. (2017) O budućnosti pozorišta. Humanistika, 1(2), str. 35-45.

(25) Intervju - Marina Kovačević, CRI: "Osuđenici ne glume, oni žive taj život“, Dom omladine Beograda, 03.09.2015., dostupno na: https://domomladine.org/intervjumarina-kovacevic-cri-osudjenici-ne-glume-oni-zive-taj-zivot/, stranici pristupljeno 29.03.2021.

(26) Jevtović, V. (2001) Uzbudljivo pozorište. Beograd: Janus.

(27) Jovanić, G., Nestorović, J., \& Petrović, V. (2019) Komparacija rizika i recidivizma osuđenih na kaznu zatvora i kućnog zatvora. Specijalna edukacija i rehabilitacija, 18(3), str. 273-298. https://doi.org/10.5937/specedreh18-23037

(28) Jovanić, G., \& Petrović, V. (2017) Uslovno otpuštanje u praksi okružnog zatvora i nadležnih sudova. Specijalna edukacija i rehabilitacija,16(1), str. 95-122 https://doi.org/10.5937/specedreh16-12680

(29) Jovićević, A., \&Vujanović, A. (2007) Uvod u studije performansa. Beograd:Fabrika knjiga.

(30) Kišjuhas, A. (2015) Telesne, individualne i društvene dimenzije emocija:ka razvoju integrisane sociološke teorije (Doktorska disertacija). Novi Sad:Univerzitet $\mathrm{u}$ Novom Sadu, Filozofski fakultet.

(31) Kišjuhas, A. (2017) Emocije i njihovi ljudi:sociologija emocija Ervinga Gofmana. Godišnjak Filozofskog Fakulteta u Novom Sadu, 42(2), 381-395. https://doi.org/10.5937/10.1909o/gff.2017.2.381-395

(32) Klajn, I., \& Šipka, M. (2007) Veliki rečnik stranih reči i izraza. Novi Sad: Prometej.

(33) Knežić, B. (2017) Obrazovanje osuđenika:način da se bude slobodan. Beograd: Institut za kriminološka i sociološka istraživanja.

(34) Kostić, M. (2007) Uspostavljanje standarda za restorativnu pravdu. Temida, 1o(1), str. 5-14.

(35) Lakićević, M., \& Knežić, B. (2011) Istraživanja u socijalnoj politici i socijalnom radu. Beograd:Fakultet političkih nauka.

(36) Langman, S., \& Pick, D. (2018) Photography as a Social Research Method. Singapore: Springer.

(37) Macanović, N., \& Nadarević, D. (2014) Penološka andragogija. Banja Luka: Evropski defendologija centar za naučna, politička, ekonomska, socijalna, bezbjednosna, sociološka i kriminološka istraživanja.

(38) Manić, Ž. (2017) Analiza sadržaja u sociologiji. Beograd: Čigoja štampa, Institut za sociološka istraživanja Filozofskog fakulteta u Beogradu. 


\section{Zbormik IKSI, 1/2O21 - A. Batrićević, M. Kovačević „Restorativni performans i resocijalizacija osuđenih lica”, (str. 25-49)}

(39) McArthur, D., \& Law, S. (1996) The Arts and Prosocial Impact Study: A Review of Current Programs and Literature. Santa Monica, California: The Rand Corporation.

(40) McLewin, A. \& Gladstone, P. (2002) An Introduction to Working with the Arts - In the Youth Justice System. UK: Unit for the Arts and Offenders, The Paul Hamlyn Foundation, The Arts Council of England and the Youth Justice Board.

(41) Milevski, V. (2013) Retributivne teorije kazne. Theoria, 56(2), str. 37-59. https://doi.org/10.2298/THEO1302037M

(42) Mimica, A., \& Bogdanović, M. (2007) Sociološki rečnik. Beograd: Zavod za udžbenike.

(43) Mirić, F. (2012) Zatvorenički društveni sistem sa posebnim osvrtom na zajednicu maloletnih osuđenika. Zbormik radova Pravnog fakulteta $u$ Nišu, Tematski broj Savremene tendencije u razvoju pravnog sistema Republike Srbije, 6o(1), str. 65-78.

(44) Nicholson, H. (2005) Applied Drama:The Gift of Theatre. New York: Palgrave Macmillan.

(45) Nikolić-Ristanović, V., \& Konstantinović-Vilić, S. (2018) Kriminologija. Beograd: Prometej.

(46) UN General Assembly, Declaration of Basic Principles of Justice for Victims of Crime and Abuse of Power :resolution / adopted by the General Assembly, 29 November 1985, A/RES/40/34, dostupno na:https://www.refworld.org/docid/3boof2275b.html, stranici pristupljeno 16.02.2021.

(47) UN Economic and Social Council (ECOSOC), UN Economic and Social Council Resolution 2002/12: Basic Principles on the Use of Restorative Justice Programmes in Criminal Matters, 24 July 2002, E/RES/2002/12, dostupno na:https://www.refworld.org/docid/46c455820.html, stranici pristupljeno 16.02.2021.

(48) Paduano, G. (2011). Antičko pozorište. Vodič kroz dela. Beograd: Clio.

(49) Perkins, D.D., \& Zimmerman, M.A. (1995) Empowerment theory, research, and application. American Journal of Community Psychology, 23(5), str. 569-579. https://doi.org/10.1007/BFo2506982

(50) Petrović, V., \& Jovanić, G. (2018) Deprivacija slobode tokom izvršenja zatvorske kazne. Specijalna edukacija i rehabilitacija, 17(4), str. 477-500. https://doi.org/10.5937/specedreh17-17878

(51) Pozorišna predstava "Zapisi iz ćelije broj 12", CRI (Centar za rehabilitaciju imaginacijom) Institut za performativne umetnosti i socijalni rad, dostupno na: https://cri.edu.rs/sr/pozorisna-predstava-zapisi-iz-celije-broj-12/, stranici pristupljeno 01.03.2021.

(52) Radojković, J. (2014) Mere za smanjenje zatvorske populacije :primeri dobre prakse. Beograd: Beogradski centar za ljudska prava.

(53) Rossner, M. (2011) Emotions and Interaction Ritual:A Micro Analysis of Restorative Justice. British Journal of Criminology, 51(1), str. 95-119. https://doi.org/10.1093/bjc/azq075

(54) Rossner, M., \& Bruce, J. (2016) Community Participation in Restorative Justice:Rituals, Reintegration, and Quasi-Professionalization. Victims and Offenders, 11(1), str. 107-125. https://doi.org/10.1080/15564886.2015.1125980

(55) Safransky, S. (ed.) (1990). Sunbeams: A Book of Quotations. Berkeley, CA: North Atlantic Books.

(56) Simonović, K. (2008) Prema sociologijskoj konceptualizaciji emocija. Socijalna ekologija, 17(2), str. 149-165.

(57) Sivi dom ulepšan umetnošću, Politika, 10.05.2020., dostupno na: http://www.politika.rs/scc/clanak/453842/Sivi-dom-ulepsan-umetnoscu, stranici pristupljeno 03.01.2021. 
(58) Soković, S. (2012) Penitensijarne statistike:mera kriminaliteta i/ili više od toga? U: Nikolić-Ristanović, V. (ur.) Evidentiranje kriminaliteta:iskustva iz sveta i Srbije. Beograd:Prometej-Beograd, str. 83-104.

(59) Spasojević, A., Janković, D. \& Kovačević, N. (2018) Podrška primeni alternatiunih sankcija i mera u Srbiji - Izveštaj i preporuke. Niš:Mreža odbora za ljudska prava u Srbiji CHRIS.

(6o) Stojanović, Z. (2018) Komentar Krivičnog zakonika. Beograd:Službeni glasnik.

(61) Ševkušić, S. (2008) Kvalitativna studija slučaja u pedagoškim istraživanjima:saznajne mogućnosti i ograničenja. Zbornik Instituta za pedagoška istraživanja, 4O(2), str. 239-256. https://doi.org/10.2298/ZIPIo802239S

(62) Špadijer-Džinić, J., Pavićević, O., \& Simeunović-Patić, B. (2009) Žena u zatvoru deprivacije zatvoreničkog života. Sociologija, 51(3),str. 225-246. https://doi.org/10.2298/SOCo903225S

(63) Tanjević, N. (2019) Uslovi boravka u ustanovama za izvršenje zatvorskih sankcija i prava lica lišenih slobode. Bezbednost, 61(1), str. 148-171. https://doi.org/10.5937/bezbednost1901148T

(64) Theatre Development Fund (2014) Theatre Development Fund Annual Report for 2013. New York: Theatre Development Fund, dostupno na: https://issuu.com/theatre_development_fund/docs/tdf_annual_interactive, stranici pristupljeno 01.04.2021.

(65) Thompson, J. (2003) Applied Theatre:Bewilderment and Beyond. Bern: European Academic Publishers.

(66) Turčilo, L., \& Kolčaković, M. (2009) Informalno obrazovanje i pozorišna drama. Obrazovanje odraslih, (2), str. 105-114.

(67) Vasiljević, Đ. (2018) Dosije Atila. Beograd: Kontrast izdavaštvo.

(68) Vasiljević-Prodanović, D. (2011) Teorije kažnjavanja i njihove penološke implikacije. Specijalna edukacija i rehabilitacija,1O(3), str. 509-525.

(69) Wrench, P. and Clarke, A. (2004) Reducing Re-offending and the Potential Contribution of the Arts. In Cowling, J. (ed.) For Art's Sake? Society and the Arts in the 21st Century, pp. 100-6. London : Institute for Public Policy Research.

(70) Zdravković, M. (2013) Pozorišni rečnik. Beograd: Zavod za udžbenike. 


\section{RESTORATIVE PERFORMANCE AND THE RESOCIALIZATION OF CONVICTED PERSONS}

Relying on up-to-now successful utilization of art (theatre, literature, painting) for the purpose of resocialization and social reintegration of convicted persons, the authors of this paper, discuss the introduction, in theory as well as in practice, the term of restorative performance, as an innovative approach to work with offenders. After analysing the term and characteristics of restorative process, on the one hand, and performance (with focus on theatre performance) on the other, the authors single out key common features of these two processes and derive the definition of a restorative performance. Furthermore, the authors present the examples of successful application of this method of work with convicted persons in Serbia, analysing, on the basis of previously conducted qualitative research, key restorative elements that can be distinguished within them, as significant factors of crime prevention. As the main purpose of this paper, the authors advocate for a broader application of restorative performance and its introduction to regular treatment programmes in institutions for the execution of criminal sanctions in Serbia, with the engagement of all relevant stakeholders and the support of community.

KEY WORDS: restorative process / performance / theatre / resocialization / prison 